\title{
Upregulation of antioxidant genes in the spermathecae of honey bee (Apis mellifera ) queens after mating
}

\author{
Alejandra N. GonZALEz ${ }^{1}$, Nancy $\mathrm{ING}^{2}$, Juliana RANGEL ${ }^{1}$ \\ ${ }^{1}$ Department of Entomology, Texas A\&M University, 2475 TAMU, College Station, TX 77843-2475, USA \\ ${ }^{2}$ Department of Animal Science, Texas A\&M University, 2471 TAMU, College Station, TX 77843-2471, USA
}

Received 4 April 2017 - Revised 18 August 2017 - Accepted 4 September 2017

\begin{abstract}
During storage, the viability of sperm in a honey bee (Apis mellifera) queen's spermatheca can be decreased by reactive oxygen species. We hypothesized that the expression of antioxidant genes would increase in queen spermathecae after mating. We measured queen morphometric characteristics and expression levels of seven antioxidant-encoding genes in virgin and mated queen spermathecae. We identified a $12 \%$ increase in body weight and a fourfold increase in ovary weight in mated queens. There was a twofold higher expression of catalase, thioredoxin 2, and thioredoxin reductase 1 in the spermathecae of mated vs. virgin queens. Expression of the other antioxidant genes (glutathione S-transferase D1, superoxide dismutase 1, vitellogenin, and glyoxalase domaincontaining 4-like (GLOD4L) in spermathecae was not different between mated and virgin queens. In drone semen, expression of antioxidant genes was overall low compared to queens except for GLOD4L, which was equivalent to that in queen spermathecae. Increased expression of antioxidant genes may assist in maintaining sperm viability inside the spermathecae of mated queens.
\end{abstract}

\section{antioxidative enzyme genes / Apis mellifera / drone / honey bee queen spermatheca / sperm}

\section{INTRODUCTION}

Reproduction requires direct interactions between sperm and eggs, and between the molecules that comprise the male seminal fluid and glandular and epithelial cells in the female reproductive organs (Heifetz and Rivlin 2010). The reproductive tract of the honey bee (Apis mellifera) queen is divided into upper and lower sections. The upper section contains the ovaries and oviducts, while the lower section contains the sperm storage organ (spermatheca), the accessory glands, and the genitalia. Sperm management (storage, maintenance, and release from storage) and fertilization occurs in the queen's lower reproductive tract (Snodgrass 1985; Heifetz and Rivlin 2010).

Corresponding author: J. Rangel, jrangel@tamu.edu Manuscript editor: Peter Rosenkranz
Despite the important role that sperm storage plays in reproduction, the molecular mechanisms by which sperms are maintained in a viable state inside the female spermathecae remain unknown.

Virgin honey bee queens mate with 10 to 15 drones in quick succession during one or two mating flights (Tarpy et al. 2004). The queen keeps less than $10 \%$ of the semen (Koeniger 1986) and only about $3 \%$ of the sperm actively migrate to the spermatheca for long-term storage over the queen's two- to three-year life span (Baer 2005). This amounts to approximately 4 to 7 million sperm cells in the spermatheca (Harbo 1986; Wilde 1994; Cobey 2007) that the queen uses to fertilize 1500-2000 eggs daily to produce female worker offspring (Winston 1987). Upon mating, the queen's abdomen and oviduct contract, transporting sperm cells to the spermaduct's orifice where most cells actively migrate to the spermatheca (Koeniger 1986). However, when live sperm 
cells are present during fertilization, they can "drag" dead sperm cells along with them to the spermatheca, and thus, live as well as dead sperm cells can be stored in the spermatheca after mating (Collins 2000).

Sperm viability is crucial for reproductive success because it sets the stage for sperm to sperm competition and thus generates selective pressures on male reproductive traits, including flight stamina to achieve copulation, and high sperm viability to maximize storage capacity in competition with other ejaculates (Berg et al. 1997; Collins and Donoghue 1999; Stürup et al. 2013). Factors in seminal fluid have been demonstrated to be crucial for sperm viability in several insect species. In Drosophila melanogaster, the seminal fluid of one male partner improves survival of all sperm collected by a female during mating (Holman 2008). In honey bees, sperm viability can be improved in vitro by incubating sperm with secretions from male accessory glands (components of seminal fluid) or spermathecae (den Boer et al. 2009). In addition, honey bee sperm incubated in vitro with untreated seminal fluid exhibits higher viability than sperm incubated in seminal fluid with heat-denatured proteins (King et al. 2011). Together, these data demonstrate the importance of seminal fluid proteins in maintaining viable sperm for long-term storage.

The metabolic activity of sperm cells during storage appears to be very important for survival. Aerobic metabolism by sperm in the spermathecae creates a dilemma: the sperm needs to produce energy to remain viable during longterm storage, but reactive oxygen-species (ROS) byproducts are produced during this time, which can lower sperm viability (Pardini 1995; Monaghan et al. 2009). Proteins that may support sperm viability have been identified through proteomic analyses of seminal fluid and spermathecal contents collected from honey bee queens before and after mating. Antioxidant proteins are present in higher quantities in the spermathecae of mated queens compared to virgin queens, and they also are present in the seminal fluid of drones (Weirich et al. 2002; Collins et al. 2004; Collins et al. 2006; Baer et al. 2009a; Baer et al. 2009b; den Boer et al. 2009; Gorshkov et al. 2015). These data suggest that an environment capable of protecting against oxidative damage can help maintain sperm viability in mated queens.

Of the 38 antioxidant genes in the honey bee genome (Corona and Robinson 2006), expression of catalase, glutathione-S-transferase D1 (GSTD1), and superoxide dismutase 1 (SOD1) genes has been investigated in the spermathecae of mated and virgin queens (Collins et al. 2004). In that study, levels of catalase and GSTD1 mRNAs were greater in the spermathecae of mated queens compared to virgin queens. In this study, we quantified the relative levels of seven antioxidant-encoding mRNAs in the spermathecae of mated and virgin honey bee queens of Apis mellifera ligustica and A. $m$. carnica strains, as well as in semen from unmated drones. The selected mRNAs encoded catalase, glyoxalase domaincontaining protein 4-like (GLOD4L), GSTD1, SOD1, thioredoxin 2 (TXN2), thioredoxin reductase 1 (TXNRD1), and vitellogenin. All of the seven gene products have roles in antioxidant pathways in honey bees (Collins et al. 2004; Seehuus et al. 2006; Baer et al. 2009a). Our hypothesis was that the expression of specific antioxidant-encoding genes is upregulated in spermathecae after mating to protect sperm from damage by ROS during storage. We identified upregulation of catalase, TXN2, and TXNRD1 genes in the spermathecae of mated queens compared to those of virgin queens. Since drone semen had low levels of those mRNAs, it appears that the spermatheca upregulates expression of those three antioxidant-encoding genes after mating.

\section{MATERIALS AND METHODS}

\subsection{Source of bees}

We obtained mated and virgin honey bee queens from a commercial queen producer located in the central valley of California (Olivarez Honey Bees, Inc., Orlando, CA). Roughly half of the queens were of "Italian" stock (presumably $A$. $m$. ligustica) and half were of "Carniolan" stock (presumably A . m . carnica). All of the queens of each stock were obtained from the same source colony and thus were sisters to each other. The individually labeled and caged queens were shipped to our laboratory facility surrounded by 
worker attendants and food. They were kept with attendants at room temperature until they were used for morphometric measurements. Sexually mature drones were collected from a designated hive located at the Janice and John G. Thomas Honey Bee Facility of Texas A\&M University's RELLIS Campus in Bryan, TX. They were placed in a cage for less than $24 \mathrm{~h}$ until semen was collected.

\subsection{Morphological measures}

Each queen was immobilized by placing her in a $-20{ }^{\circ} \mathrm{C}$ freezer for 3 to $5 \mathrm{~min}$. Once immobilized, her fresh weight was measured to the nearest $0.1 \mathrm{mg}$ on a digital scale. Then, her head and thorax widths were measured three times to within $0.1 \mathrm{~mm}$ using digital calipers, and the threemeasurement averages were calculated. All queens were sacrificed by decapitation on a bed of dry ice to keep all tissues suitable for RNA extraction. We then dissected each queen's ovaries and spermatheca from the abdomen. The wet weight of the two ovaries was measured to the nearest $0.1 \mathrm{mg}$ on a digital scale. The tracheal net was removed from the spermatheca with forceps and then the spermatheca was pressed against the wall of an Eppendorf tube to release the contents therein. A small amount of semen from four mated Italian and four mated Carniolan queens was collected and sampled immediately for sperm viability analysis. The rest of the spermathecal samples from virgin and mated queens were frozen individually at $-80{ }^{\circ} \mathrm{C}$ until they were used for RNA extraction (see below). Likewise, drones were sacrificed by decapitation. Semen was collected from each drone by everting the endophallus and by using a micropipette to harvest the semen on top of the mucus, as previously described (Cobey 2007). The drone semen samples were frozen individually at $-80{ }^{\circ} \mathrm{C}$ until they were used for RNA extraction (see below).

\subsection{Sperm counts and viability}

We used a staining protocol following the general guidelines outlined by Collins and Donoghue (1999) to quantify sperm number and viability in the semen collected from the spermathecae of mated queens. A LIVE/DEAD Sperm Viability
Kit from Molecular Probes (Eugene, OR) was used with the following modifications: Briefly, immediately after dissection, the queen's spermatheca was placed in a microcentrifuge tube with $200 \mu \mathrm{L}$ of $10 \mathrm{mM}$ HEPES, $150 \mathrm{mM} \mathrm{NaCl}$, and $10 \%$ BSA, pH 7.4. The spermatheca was squeezed with forceps to break it open and release the sperm. The spermathecal tissue was allowed to settle before we harvested $100 \mu \mathrm{L}$ from the top of the solution for the sperm counting and viability assay. To perform the sperm viability assay, we added $6 \mu \mathrm{L}$ of $1 \mathrm{mM}$ SYBR 14 in DMSO and $6 \mu \mathrm{L}$ of $2.4 \mathrm{mM}$ propidium iodide in water to the $100-\mu \mathrm{L}$ solution containing sperm and incubated it for $8 \mathrm{~min}$ in the dark. Brightfield cell counting was used to estimate sperm cell concentration, while dual fluorescent filters were used to measure sperm viability by estimating the proportion of live sperm in the total cell count for each sample. Live sperm fluoresce at green wavelengths (520 to $570 \mathrm{~nm}$ ), while dead sperm fluoresce at red wavelengths (approximately $650 \mathrm{~nm}$; Collins and Donoghue 1999). The stained sperm solution $(20 \mu \mathrm{L})$ was immediately loaded onto a slide and allowed to settle for $5 \mathrm{~min}$ before conducting the automated cell-counting analysis using a Vision CBA Analysis System ${ }^{\circledR}$ (Nexcelom Bioscience; Lawrence, MA). The average number of live and dead sperm cells was counted twice for each sample, and the average was corrected for the dilution factor to estimate the total number of sperm cells.

\subsection{RNA purification and production of complementary DNA (cDNA)}

Spermathecae were individually placed in a 1.5-mL microtubes with $50 \mu \mathrm{L}$ PureZOL ${ }^{\mathrm{TM}}$ RNA isolation reagent (BIO-RAD). The same RNA isolation procedure was done for semen collected from drones. The tissues in PureZOL were ground with a VWR® pellet mixer (catalog number 47747-307, VWR®, Radnor, PA). We followed the standard RNA-extraction protocol for PureZOL ${ }^{\mathrm{TM}}$. The precipitation step was done overnight at $-20{ }^{\circ} \mathrm{C}$ after adding $1 \mu \mathrm{L}$ of $20 \mu \mathrm{g} / \mu \mathrm{L}$ RNAse-free glycogen. RNA was pelleted during 10 min of centrifugation at $12,000 \times g$ in a $4{ }^{\circ} \mathrm{C}$ microcentrifuge. RNA pellets were washed in 
$75 \%$ ethanol, air dried for $10 \mathrm{~min}$, and resuspended in $25 \mu \mathrm{L}$ of nuclease-free water. RNA concentrations were measured in a Qubit ${ }^{\circledR 2}$.0 fluorometer with a Qubit ${ }^{\circ}$ RNA HS Assay Kit (Life Technologies Corporation, Grand Island, NY). Fifty nanograms of each RNA sample was processed to remove genomic DNA with an iScript ${ }^{\mathrm{TM}} \mathrm{gDNA}$ Clear cDNA Synthesis Kit (BIO-RAD)®. Then, the kit, employing both oligo dT and random primers, was used to produce $20 \mu \mathrm{L}$ of cDNA per sample.

\subsection{Quantitative PCR analysis}

The cDNA samples were diluted in a 1:4 ratio with nuclease-free water, and $1 \mu \mathrm{L}$ of the diluted sample was used to perform replicate $10-\mu \mathrm{L}$ quantitative-PCR (qPCR) reactions. The primers utilized to amplify each gene product (Table I) were synthesized by Integrated DNA Technologies (Coralville, IA). All newly designed primers were made to amplify across a large intron to add specificity for amplification of cDNA and not genomic DNA. The qPCR reactions were performed with the SsoAdvanced ${ }^{\mathrm{TM}}$ Universal SYBR® Green Supermix kit, which uses a Sso7d fusion polymerase enzyme (BIO-RAD®). The qPCR was performed in a CFX96 ${ }^{\mathrm{TM}}$ Real-time system (BIO-RAD®). The cycling program was $95{ }^{\circ} \mathrm{C}$ for $30 \mathrm{~s}$ followed by 39 cycles at $95{ }^{\circ} \mathrm{C}$ for $5 \mathrm{~s}, 61{ }^{\circ} \mathrm{C}$ for $10 \mathrm{~s}$, followed by a melting curve from 65 to $95{ }^{\circ} \mathrm{C}$ in $0.5^{\circ} \mathrm{C}$ increments. All of the amplicons melted at their individual predicted temperatures. Gene expression was normalized to the expression of the normalizer genes RPL8 and RPS5. Normalized values were calculated utilizing the CFX Manager ${ }^{\mathrm{TM}}$ Software and reported as " $2-\Delta \Delta \mathrm{Ct}$ " values. The coefficient of variation $(\mathrm{CV} \%)$ and average expression stability ( $M$ value) of the tested genes were $\mathrm{CV}=0.1702$ and $M=0.4826$.

\subsection{Statistical analysis}

We used one-way ANOVA tests to determine whether there were differences in the morphometric measurements of Carniolan and Italian queens. We also performed one-way ANOVA tests to determine if there were statistical differences in gene expression values between spermathecae of virgin and mated queens and drone semen. In cases where we found statistical differences between queens and drones, we conducted pairwise Student's $t$ tests to discern differences between two tissue types. All tests were performed using the statistical software JMP® 12.0 (SAS Inc., Cary, NC). We set the level of statistical significance at $\alpha=0.05$ for all tests and report all descriptive statistics as means \pm standard errors of the mean (S.E.M.).

\section{RESULTS}

\subsection{Morphometric, gene-expression, and sperm measurements in spermathecae were not different between Italian and Carniolan queens}

We found no statistically significant differences between virgin Carniolan and virgin Italian queens for any of the morphometric measurements or any of the gene expression values for the seven genes measured (Table II). However, there was a trend $(P=0.07)$ for a fourfold higher level of GSTD1 gene expression in the spermathecae of virgin Italian queens compared to virgin Carniolan queens. Likewise, we did not find any statistical significant differences for any of the morphometric characters or normalized gene expression values measured from mated Carniolan and mated Italian queens (Table II). Furthermore, we did not find statistical differences in spermathecal sperm counts or sperm viability between Carniolan and Italian mated queens (Table II). Based on these results, we grouped all virgin-queen and mated-queen data into single categories for further statistical analysis, regardless of the genetic stock of the queens.

\subsection{Morphometric differences between virgin and mated queens}

For most morphometric measurements, we collected data from 10 virgin and 18 mated queens, unless otherwise noted in the tables. Not surprisingly, the wet weight of mated queens was on average $12 \%$ greater than that of virgin queens (Table III). We found no 
Table I. Primer sequences used for quantitative reverse-transcription PCR, in alphabetical order

\begin{tabular}{llll}
\hline Primer & Sequence (5'-3') & Amplicon size (bp) & $\begin{array}{l}\text { GenBank accession } \\
\text { number }\end{array}$ \\
\hline Catalase F & CCTTCCGCTGACCAGTTAAT & 106 & AF436842.1 \\
Catalase R & ACCGTCAAACTGGCTTTCT & & AF436842.1 \\
GLOD4L F & GGAATTTGCTGAAGGTTGCG & 94 & XM_625097.3 \\
GLOD4L R & ATGAGTATCTTCTGTTCCATATCCTATC & & XM_625097.3 \\
GSTD1 F* & CAATTTGATGAACGGGGAAC & 306 & BE844335.1 \\
GSTD1 R* & GCCGTACCGATGTTTCGTA & & BE844335.1 \\
RPL8 F* & TGGATGTTCAACAGGGTTCATA & 122 & XM_393671.5 \\
RPL8 R* & CTGGTGGTGGACGTATTGATAA & & XM_393671.5 \\
RPS5 F & CCAAAGAAGACGTGAACGAAAG & 104 & XM_006570237 \\
RPS5 R & AGAAAGGGCCACTGGTAATG & & XM_006570237 \\
SOD1 F & GGAGAGTACCAATTCCGTGAAG & 133 & NM_001178027.1 \\
SOD1 R & CTAATGGGTTGAAATGTGCACC & & XM_001178027.1 \\
TXN2 F & GGTTTACCAAATTAAGAATGCCAGT & 98 & XM_003250360 \\
TXN2 R & GACCACACCACATAGCAAAGA & & NM_001178025.1 \\
TXNRD1 F & CTGATTGCTGTAGGTGGTAGAC & 149 & NM_001178025.1 \\
TXNRD1 R & CCAGCACATTCTAAACCAATATATCC & & NM_001011578.1 \\
Vitellogenin F & GAACCTGGAACGAACAAGAATG & 98 & NM_001011578.1 \\
Vitellogenin R & CGACGATTGGATGGTGAAATG & & \\
\hline
\end{tabular}

*from Collins et al. (2004)

differences in head or thorax width between virgin and mated queens (Table III). Also, not surprisingly, the wet weight of the ovaries showed the greatest change in mated queens, as it was more than five times higher that of virgin queens. On average for all mated queens analyzed, the spermathecal sperm counts were $(6.83 \pm 0.44) \times 10^{6}$ sperm cells and the sperm viability was $94.44 \pm 1.47 \%$ (Table II).

\subsection{Identified differences in expression levels of seven antioxidant genes in the spermathecae of mated and virgin queens and drone semen}

Figure 1 reports normalized expression $\left(2^{-\Delta \Delta \mathrm{Ct}}\right)$ values for the seven antioxidantencoding genes explored in the spermathecae of mated and virgin queens and in drone semen (mean \pm S.E.M.). We identified statistically significant differences across all three sample types for the expression of catalase $\left(F_{2,27}=6.55, P\right.$
$=0.005), \mathrm{SOD} 1\left(F_{2,28}=10.01, P\right.$ value $\left.=0.0005\right)$, TXN2 $\left(F_{2,28}=14.95, P<0.0001\right)$, and TXNRD1 $\left(F_{2,28}=7.67, P=0.002\right)$ genes. Conversely, we did not find any statistical differences across all three sample types for the expression of GLOD4L $\left(F_{2,28}=0.10, P=0.90\right)$, GSTD1 $\left(F_{2,24}=2.80, P\right.$ $=0.08)$, and vitellogenin $\left(F_{2,23}=0.36, P=0.70\right)$ genes.

For those genes that revealed significant differences across all three samples, further pairwise comparisons between tissue types revealed that expression of the catalase gene was almost two times greater in the spermathecae of mated queens compared to that of virgin queens $(t=-2.31$, $P=0.03)$ and 15 times greater than that in drone semen $(t=3.36, P=0.002$; Figure 1a). Expression of the TXN2 gene was almost two times greater in the spermathecae of mated queens than in those of virgin queens $(t=-2.65, P=0.01)$ and five times greater than that in drone semen $(t=5.38, P<0.0001$; Figure 1d). Moreover, expression of the TXN2 gene was three times 


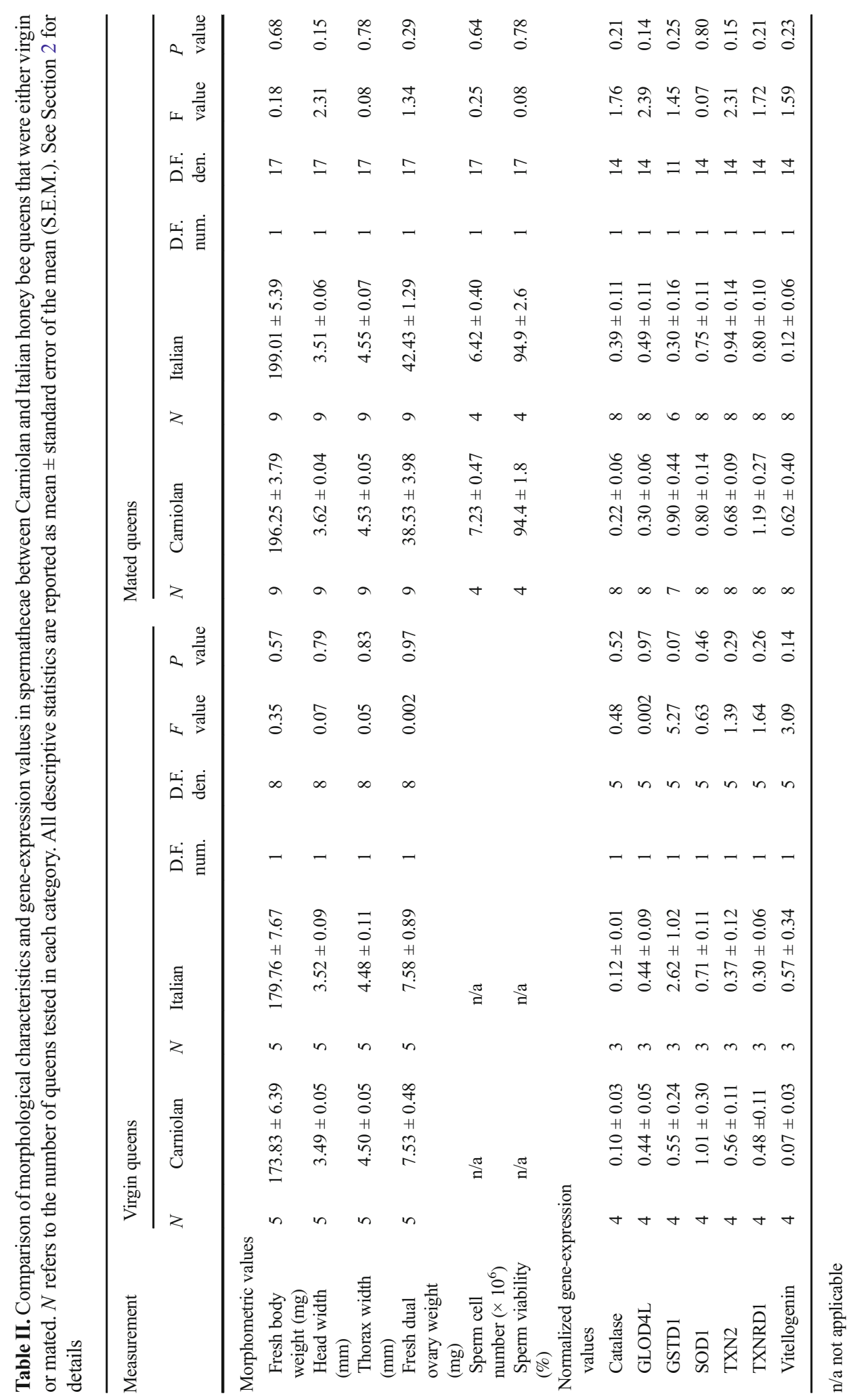


greater in spermathecae of virgin queens compared to drone semen $(t=2.18, P=0.03)$. The expression levels of the functionally related TXNRD1 gene in the spermathecae of mated queens were almost three times greater than in the spermathecae of virgin queens $(t=-2.90$, $P=0.007$; Figure 1d) as well as in the semen of drones ( $t=3.42, P=0.002$; Figure 1e). Likewise, levels of SOD1 mRNA were four times greater in the spermathecae of mated queens compared to drone semen $(t=3.97, P=0.0004)$ and almost four times greater in the spermathecae of virgin queens compared to drone semen $(t=3.92$, $P=0.0005$; Figure 1f).

Interestingly, although the overall expression of the GSTD1 gene was not statistically significant across all three tissue types $(P=0.08)$, its expression was 7.5 times greater in the spermathecae of virgin queens compared to drone semen $(t=2.31, P=0.03$; Figure $1 \mathrm{c})$. We did not find significant pairwise differences in the expression of GLOD4L (Figure 1b) or vitellogenin (Figure $1 \mathrm{~g}$ ) genes in the tissues analyzed. As expected, there was negligible expression of the vitellogenin gene in drone semen compared to that in the spermathecae of virgin and mated queens. The variation in vitellogenin gene expression between individual spermathecae precluded identification of a difference between spermathecal values and those of semen. The concentrations of catalase, TXN2, and TXNRD1 mRNAs were three to 14 times lower in drone semen than in the spermathecae of mated queens (Figure 1). Together, the data indicate that honey bee spermathecae upregulate expression of at least four antioxidantencoding genes after mating.

\section{DISCUSSION}

Apis mellifera ligustica ("Italian") and A.m. carnica ("Carniolan") are honey bee subspecies that come from regions near the Mediterranean Sea. Despite their close geographical precedence, they differ phenotypically and in behavior. For example, Italian bees, the dominant subspecies introduced into North America and Europe, are yellowish-brown and exhibit low swarming tendencies. In contrast, the Carniolan bees are darker in color, better house cleaners, less aggressive, and more resistant to disease (Caron and Connor 2013). Even though there are genetic differences between these two subspecies, we found no differences between Italian and Carniolan queens morphometrically or in spermathecal expression of antioxidant-encoding genes. Not surprisingly, in both subspecies, ovary and wet body weights were greater in mated compared to virgin queens, which is explained by the fact that ovary development is triggered by mating (Winston 1987).

We discovered higher levels of expression of the catalase, TXN2, and TXNRD1 genes in spermathecae of mated queens compared to those of virgin queens. Likewise, Weirich et al. (2002) found catalase, GSTD1, and SOD1 to be catalytically active enzymes in honey bee spermathecae. They also reported that activities of catalase and GSTD1 enzymes were elevated in the spermathecae of mated queens compared to virgin queens. In contrast, levels of SOD1 activity were not different between spermathecae of mated and virgin queens. The increase of catalase mRNA levels in the spermathecae after mating has been described by Collins et al. (2004). However, that study also identified an increase in GSTD1 mRNA levels at 21 days post-mating which we did not find, possibly due to differences in the protocols. The 2004 study, which used Italian bees from a Claxton, GA apiary, only found increased levels of GSTD1 mRNA in the queen spermathecae at 21 days post-mating and not at a later time point, so perhaps the effect is transient. Furthermore, our cDNA synthesis utilized both oligo(dT) and random primers while Collins et al. (2004) utilized only oligo(dT) primers. As a consequence of the latter, the reverse transcriptase would have to synthesize 676 bases of GSTD1 cDNA (GenBank accession NM_001178028.1) through the entire 3' untranslated region and $84 \%$ of the coding sequence to produce the amplicon in quantitative PCR. Moreover, our results showed that drone semen contained low levels of all the antioxidant-encoding transcripts we analyzed except GLOD4L mRNA relative to those in queen spermathecae. Therefore, it appears that spermathecae indeed upregulate expression of catalase, TXN2, and TXNRD1 genes after mating.

The expression of antioxidant-encoding genes in reproductive tracts is widely conserved across species from insects, to birds, to mammals (Aitken 
Table III. Comparison of morphological characteristics between virgin and mated honey bee queens. $N$ refers to the number of queens tested in each category. All descriptive statistics are reported as mean \pm standard error of the mean (S.E.M.). Statistically significant $P$ values are given in italics

\begin{tabular}{|c|c|c|c|c|c|c|c|c|}
\hline \multirow{2}{*}{$\begin{array}{l}\text { Morphometric } \\
\text { character measured }\end{array}$} & \multicolumn{2}{|c|}{ Virgin queens } & \multicolumn{2}{|c|}{ Mated queens } & \multicolumn{4}{|c|}{ One-way ANOVA values } \\
\hline & $N$ & Mean \pm S.E.M. & $N$ & Mean \pm S.E.M. & $\begin{array}{l}\text { D.F. } \\
\text { num. }\end{array}$ & $\begin{array}{l}\text { D.F. } \\
\text { den. }\end{array}$ & $\begin{array}{c}\mathrm{F} \\
\text { value }\end{array}$ & $P$ value \\
\hline Fresh body weight (mg) & 10 & $176.80 \pm 4.81$ & 18 & $197.63 \pm 3.21$ & 1 & 26 & 13.84 & $0.001 *$ \\
\hline Head width (mm) & 10 & $3.50 \pm 0.05$ & 18 & $3.57 \pm 0.04$ & 1 & 26 & 0.96 & 0.34 \\
\hline Thorax width (mm) & 10 & $4.49 \pm 0.06$ & 18 & $4.54 \pm 0.04$ & 1 & 26 & 0.47 & 0.5 \\
\hline $\begin{array}{l}\text { Fresh dual ovary } \\
\text { weight (mg) }\end{array}$ & 10 & $7.55 \pm 0.48$ & 8 & $40.97 \pm 1.67$ & 1 & 16 & 447.98 & $<0.0001 * *$ \\
\hline $\begin{array}{l}\text { Sperm cell number } \\
\left(\times 10^{6}\right)\end{array}$ & & $\mathrm{n} / \mathrm{a}$ & 8 & $6.83 \pm 0.44$ & & & & \\
\hline Sperm viability (\%) & & $\mathrm{n} / \mathrm{a}$ & 8 & $94.44 \pm 1.47$ & & & & \\
\hline
\end{tabular}

* Differences with $P \leq 0.001$. ** Differences with $P \leq 0.0001$

$\mathrm{n} / \mathrm{a}$ not applicable

and Fisher 1994; Bilodeau et al. 2002; Collins et al. 2004; Lapointe and Bilodeau 2003; Seehuus et al. 2006; Tavilani et al. 2008; Heifetz and Rivlin 2010; Malta et al. 2014; Du et al. 2015). Thioredoxins, including TXN2 and TXNRD1, are a family of antioxidant proteins that have been largely conserved from bacteria to mammals (Meyer et al. 2009). There are multiple antioxidant enzymes in the thioredoxin family, which can specifically interact with a target protein and reduce a disulfide bond. In D. melanogaster, the related gene-encoding gluthathione reductase is lacking and thioredoxin-related gene products are the predominant enzymes with antioxidant activities (Kanzok et al. 2001; Koo et al. 2016). For instance, TXN2 mutant fruit flies have greater oxidative stress and shorter life spans (Svensson and Larsson 2007). In mammalian systems, expression of thioredoxin-associated genes appears to be crucial for spermatogenesis and other developmental processes (Meyer et al. 2009). TXNRD1 has two redox-active sites compared to one in glutathione reductase (Mustacich and Powis 2000). Because of this, TXNRD1 has a much greater number of substrates than glutathione reductase. TXNRD1 functions not only in oxidant injury prevention, but also in cell growth, DNA synthesis, and regulation of gene expression. TXN2 is in the mitochondria, which have recently been recognized as regulators of the concentrations of reactive oxygen species (Munro and Treberg 2017).

The honey bee genome has seven genes related to the thioredoxin family (Corona and Robinson 2006). The TXN2 and TXNRD1 proteins were found to be present in the spermathecal fluid of mated queens (Baer et al. 2009a). Our results of greater TXN2, TXNRD1, and catalase expression in the spermathecae of mated compared to virgin queens suggest that the genes may be transcriptionally induced after mating. Factors leading to enhanced expression of these genes may be from sperm or seminal fluid or from physiological alterations of the queen as she initiates egg production. In future studies, it will be exciting to define the molecular mechanism responsible for the upregulation of antioxidant genes in queen spermathecae.

Reproduction is critically important to fitness, as failure to reproduce will compromise species survival. In honey bees, reproduction of the colony depends solely on the reproductive capacity of a single queen, the quality of her drone partners, and the viability of the sperm she stores after mating. Consequently, workers have developed mechanisms to recognize a decrease in the queen's ability to lay fertilized eggs and to rapidly begin a queen replacement process (i.e., 

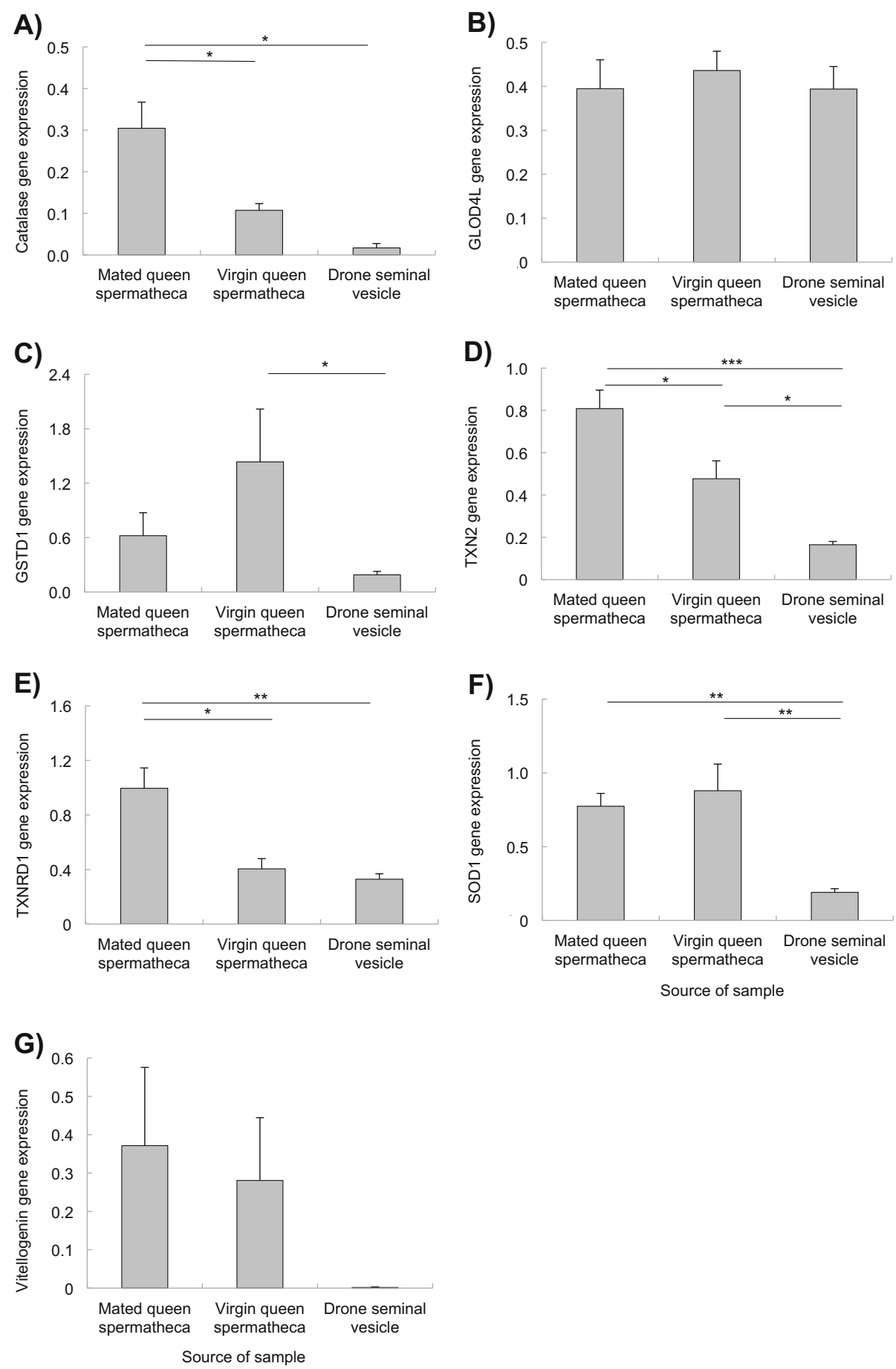

Figure 1. Normalized expression of seven antioxidant genes in the spermathecae of mated and virgin queens and the semen of sexually mature drones (panels $\mathbf{a}-\mathbf{g}$ ). Gene expression was normalized to the expression of the normalizer genes RPL8 and RPS5 and reported as the mean \pm standard error of the mean (S.E.M.). Statistically significant pairwise differences between two tissue groups are represented by connecting lines and asterisks above the bars. * Values of $P \leq 0.05$. ** Values of $P \leq 0.001$. *** Values of $P \leq 0.0001$. See Section 2 for details. 
"supersedure") if the queen fails in her egg-laying duties. Creation of a replacement queen is energetically costly and, if resources are scarce, it may cause a colony to collapse (Rangel et al. 2012). Therefore, it is advantageous for the colony to have long-lived queens with viable sperm in the spermatheca. During storage, sperm metabolism produces ROS, which can impair sperm viability. The expression of antioxidant genes in the spermatheca of mated queens is likely needed to protect sperm from ROS during their long-term storage. Interestingly, Verma and Shuel (1973) discovered that stored semen showed only $40 \%$ of the oxygen uptake of freshly ejaculated semen, thus exhibiting significantly lower rates of oxygen consumption and conservation of energy in semen stored in the spermatheca. Therefore, the high density of sperm in the spermatheca, as well as the low metabolic activity that it undergoes during storage, may also play important roles in the queen's successful long-term storage of sperm. The honey bee queen's spermatheca presents itself as an example of how evolution can meticulously craft a reproductive organ to overcome strong physiological and environmental constraints to maintain its vigor over time.

\section{ACKNOWLEDGEMENTS}

We would like to thank Tammy Olivarez for donating the honey bee queens used in our study. We thank ET Ash and Adrian Fisher II for their assistance in collecting drone samples at the Janice and John G. Thomas Honey Bee Facility at Texas A\&M University.

\section{AUTHORS CONTRIBUTION}

ANG, NI and JR conceived this research, designed experiments and interpreted the data; ANG performed experiments; ANG, NI and JR performed the analysis, wrote the paper and participated in the revisions of it. All authors read and approved the final manuscript.

Funding This study was funded in part by a USDANIFA grant to JR and NI (award number 2015-6701323170) and the Texas AgriLife Research Hatch Project number TEX09557.

\section{COMPLIANCE WITH ETHICAL STANDARDS}

Conflict of interest The authors declare that they have no potential conflict of interest in relation to the study in this paper.

Régulation à la hausse de gènes antioxydants dans les spermathèques de reines d'abeilles (Apis mellifera) après accouplement

gène d'enzymes antioxydantes / Apidae / mâle / abeille / spermathèque / reine / sperme

Upregulation von antioxidativen Genen in der Spermatheka von Bienenköniginnen (Apis mellifera) nach der Paarung

Antioxidative Enzymgene / Apis mellifera / Drohnen / Bienenkönigin / Spermatheka / Spermien

\section{REFERENCES}

Aitken, J., Fisher, H. (1994) Reactive oxygen species generation and human spermatozoa: the balance of benefit and risk. Bioessays 16, 259-67

Baer, B. (2005) Sexual selection in Apis bees. Apidologie 36, 187-200

Baer, B., Eubel, H., Taylor, N.L., O'Toole, N., Millar, A.H. (2009a) Insights into female sperm storage from the spermathecal fluid proteome of the honeybee Apis mellifera. Genome Biol, 10 : R67

Baer, B., Heazlewood, J.L., Taylor, N.L., Eubel, H., Millar, A.H. (2009b) The seminal fluid proteome of the honeybee Apis mellifera. Proteomics 9, 2085-2097

Berg, S., Koeniger, N., Koeniger, G., Fuchs, S. (1997) Body size and reproductive success of drones (Apis mellifera L). Apidologie 28, 449-460

Bilodeau, J.F., Blanchette, S., Cormier, N., Sirard, M.A. (2002) Reactive oxygen species-mediated loss of bovine sperm motility in egg yolk Tris extender: protection by pyruvate, metal chelators and bovine liver or oviductal fluid catalase. Theriogenology 57, 1105-22

Caron, D.M., Connor, L.J. (2013) Honey Bee Biology and Beekeeping, Revised Edition. Wicwas Press, Kalamazoo, MI

Cobey, S.W. (2007) Comparison studies of instrumentally inseminated and naturally mated honey bee queens and factors affecting their performance. Apidologie 38, 390-410.

Collins, A.M. (2000) Relationship between semen quality and performance of instrumentally inseminated honey bee queens. Apidologie 31 , 421-429 
Collins, A.M., Donoghue, A.M. (1999) Viability assessment of honey bee, Apis mellifera, sperm using dual fluorescent staining. Theriogenology 51, 1513-1523

Collins, A.M., Williams, V., Evans, J.D. (2004) Sperm storage and antioxidative enzyme expression in the honey bee, Apis mellifera . Insect Mol. Biol. 13, 141-6

Collins, A.M., Caperna, T.J., Williams, V., Garrett, W.M., Evans, J.D. (2006) Proteomic analyses of male contributions to honey bee sperm storage and mating. Insect Mol. Biol. 15, 541-549

Corona, M., Robinson, G.E. (2006) Genes of the antioxidant system of the honey bee: annotation and phylogeny. Insect Mol. Biol. 15, 687-701

den Boer, S.P.A., Boomsma, J.J., Baer, B. (2009) Honey bee males and queens use glandular secretions to enhance sperm viability before and after storage. J. Insect Physiol. 55, 538-543

Du, J., Hincke, M.T., Rose-Martel, M., Hennequet-Antier, C., Brionne, A., Cogburn, L.A., Nys, Y., Gauron, J. (2015) Identifying specific proteins involved in eggshell membrane formation using gene expression analysis and bioinformatics. BMC Genomics 16: 792

Gorshkov, V., Blenau, W., Koeniger, G., Römpp, A., Vilcinskas, A., Spengler, B. (2015) Protein and peptide composition of male accessory glands of Apis mellifera drones investigated by mass spectrometry. PLoS ONE $10: \mathrm{e} 0125068$

Harbo, J.R. (1986) Propagation and instrumental insemination, In: Rinderer T.E. (Ed.), Bee Breeding and Genetics. Academic Press, Inc., Orlando, FL. pp. 361-389

Heifetz, Y., Rivlin, P.K. (2010) Beyond the mouse model: Using Drosophila as a model for sperm interaction with the female reproductive tract. Theriogenology 73 , 723-739

Holman, L. (2008) Drosophila melanogaster seminal fluid can protect the sperm of other males. Funct. Ecol. 23, 180-186

Kanzok, S.M., Fechner, A., Bauer, H., Ulschmid, J.K., Muller, H.M., Botella-Munoz, J.Schneuwly, S., Schrmer, R., Becker, K. (2001) substitution of the thioredoxin system for glutathione reductase in Drosophila melanogaster. Science 291, 643-646

King, M., Eubel, H., Millar, A.H., Baer, B. (2011) Proteins within the seminal fluid are crucial to keep sperm viable in the honeybee Apis mellifera. J. Insect Physiol. 57, 409-414

Koeniger, G. (1986) Reproduction and mating behavior, in: Rinderer T.E. (Ed.), Bee Breeding and Genetics. Academic Press, Inc., Orlando, FL, pp. 235-252

Koo, H.-N., Lee, S.G., Yun, S.-H., Kim, H.K., Choi, Y.S., Kim G.-H. (2016) Comparative analyses of $\mathrm{Cu}-\mathrm{Zn}$ superoxide dismutase (SOD1) and thioredoxin reductase (TrxR) at the mRNA level between Apis mellifera L. and Apis cerana F. (Hymenoptera: Apidae) under stress conditions. J. Insect Sci. 16:1-6

Lapointe, J., Bilodeau, J.F. (2003) Antioxidant defenses are modulated in the cow oviduct during the estrous cycle. Biol. Reprod. 68, 1157-64
Malta, J., Martins, G.F., Marques, A.E., Games, P.D., Zanuncio, J.C., Baracat-Pereira, M.C., Salomão, T.M.F. (2014) Insights into the proteome of the spermatheca of the leaf-cutting ant Atta sexdens rubropilosa (Hymenoptera: Formicidae). Fla. Entomol. 97, 1856-1861

Meyer, Y., Buchanan, B.B., Vignols, F., Reichheld, J.-P. (2009) Thioredoxins and glutaredoxins: unifying elements in redox biology. Annu. Rev. Genet. 43, 335-67

Monaghan, P., Metcalfe, N.B., Torres, R. (2009) Oxidative stress as a mediator of life history trade-offs: mechanisms, measurements and interpretation. Ecol. Lett. 12, 75-92

Munro, D., Treberg, J.R. (2017) A radical shift in perspective: mitochondria as regulators of reactive oxygen species. J Exper. Biol. 220, 1170-1180

Mustacich, D., Powis, G. (2000) Thioredoxin reductase. Biochem. J. 346, 1-8

Pardini, R.S. (1995) Toxicity of oxygen from naturally occurring redox-active pro-oxidants. Arch. Insect Biochem. 29, 101-118

Rangel, J., Keller, J. J., Tarpy, D. R. (2012) The effects of honey bee (Apis mellifera L.) queen reproductive potential on colony growth. Insectes Soc. 60, 65-73

Seehuus, S.C., Norberg, K., Gimsa, U., Krekling, T., Amdam, G.V. (2006) Reproductive protein protects functionally sterile honey bee workers from oxidative stress. Proc. Natl. Acad. Sci. U. S. A. 103, 962-7

Snodgrass, R.E. (1985) Anatomy of the Honey Bee. Cornell University Press, Ithaca, NY

Stürup, M., Baer-Imhoof, B., Nash, D.R., Boomsma, J.J., Baer, B. (2013) When every sperm counts: factors affecting male fertility in the honeybee Apis mellifera . Behav. Ecol. 24, 1192-1198

Svensson, M.J., Larsson, J. (2007) Thioredoxin-2 affects lifespan and oxidative stress in Drosophila. Hereditas 144, 25-32

Tarpy, D.R., Nielsen, R., Nielsen, D.I. (2004) A scientific note on the revised estimates of effective paternity frequency in Apis. Insectes Soc. 51, 203-204

Tavilani, H., Goodarzi, M.T., Vaisi-raygani, A., Salimi, S., Hassanzadeh, T. (2008) Activity of antioxidant enzymes in seminal plasma and their relationship with lipid peroxidation of spermatozoa. Int. Braz. J. Urol. 34, 485-91

Verma, L.R., Shuel, R.W. (1973) Respiratory metabolism of the semen of the honey-bee, Apis mellifera. J. Insect Physiol. 19, 97-103

Weirich, G.F., Collins, A.M., Williams, V.P. (2002) Antioxidant enzymes in the honey bee, Apis mellifera. Apidologie 33, 3-14

Wilde, J. (1994) Comparison of the development and productivity of bee colonies with naturally and instrumentally inseminated queens kept in different conditions before and after the insemination. Zootechnica 39, 135-152

Winston, M.L. (1987) The Biology of the Honey Bee. Harvard University Press, Cambridge, MA 